\title{
Anaerovirgula multivorans gen. nov., sp. nov., a novel spore-forming, alkaliphilic anaerobe isolated from Owens Lake, California, USA
}

\author{
Correspondence \\ Elena V. Pikuta \\ elenapikuta@hotmail.com \\ Richard B. Hoover \\ Richard.Hoover@NASA.GOV
}

\author{
Elena V. Pikuta, ${ }^{1}$ Takashi Itoh, $^{2}$ Paul Krader, ${ }^{3}$ Jane Tang, ${ }^{4}$ \\ William B. Whitman ${ }^{5}$ and Richard B. Hoover ${ }^{1}$ \\ ${ }^{1}$ National Space Sciences and Technology Center/NASA, XD-12, 320 Sparkman Dr., \\ Astrobiology Laboratory, Huntsville, AL 35805, USA \\ 2Japan Collection of Microorganisms, RIKEN BioResource Center, 2-1 Hirosawa, Wako-shi, \\ Saitama 351-0198, Japan \\ ${ }^{3}$ American Type Culture Collection, 10801 University Blvd, Manassas, VA 20110, USA \\ ${ }^{4}$ United States Department of Agriculture, Monitoring Programs Office, 8609 Sudley Rd, suite \\ 206, Manassas, VA 20110, USA \\ ${ }^{5}$ Department of Microbiology, University of Georgia, Athens, GA 30602-2605, USA
}

Aerobic and anaerobic micro-organisms hydrolysing cellulose in alkaline ecosystems have not been well characterized (Lynd et al., 2002). In our laboratory, the process of cellulose degradation was studied with anaerobic sediments from alkaline Owens Lake, California, USA. At room temperature, a piece of filter paper was completely dissolved over a period of 7-10 days. The dominant bacterial forms observed microscopically were motile rods

The GenBank/EMBL/DDBJ accession number for the 16S rRNA gene sequence of strain $\mathrm{SCA}^{\top}$ is $\mathrm{AB} 201750$.

Images of cells of strain $\mathrm{SCA}^{\top}$ and graphs showing growth of the strain under varying salinity, $\mathrm{pH}$ and temperature conditions are available as supplementary material in IJSEM Online. and spirochaetes (Pikuta et al., 2005). Subsequent isolation of both of these morphotypes led to the characterization of two saccharolytic strains, $\mathrm{SCA}^{\mathrm{T}}$ and $\mathrm{ASpC} 2^{\mathrm{T}}$. The study showed that in addition to the hydrolysis of cellulose, strain $\mathrm{ASpC2}{ }^{\mathrm{T}}$ was able to ferment sugars, but strain $\mathrm{SCA}^{\mathrm{T}}$ exhibited a much broader fermentative metabolism; it fermented sugars, some organic acids, amino acids and proteolysis products. In pure or binary cultures, these isolates exhibited a weak ability to hydrolyse cellulose, but only in the presence of yeast extract. Here we present a taxonomic description of the obligately anaerobic strain $\mathrm{SCA}^{\mathrm{T}}$ which, based on its phenotypic and genotypic features, is considered to represent a novel species of a new genus within clostridial cluster XI. 
Black mud sediments with a $\mathrm{pH}$ of $10 \cdot 0$ and a strong smell of hydrogen sulfide were collected anaerobically from beneath shallow water (temperature $30{ }^{\circ} \mathrm{C}$, salinity $3 \%$ ) on the eastern side of Owens Lake in August 2000. Sampling, maintenance, transportation and storage were as previously described by Hoover et al. (2003) and Pikuta et al. (2003a). Enrichment cultures were obtained using an anaerobic technique and the medium contained (per litre): $30 \mathrm{~g} \mathrm{NaCl}$, $2 \cdot 76 \mathrm{~g} \mathrm{Na}_{2} \mathrm{CO}_{3}, 24 \cdot 0 \mathrm{~g} \mathrm{NaHCO}_{3}, 0 \cdot 2 \mathrm{~g} \mathrm{KCl}, 0 \cdot 2 \mathrm{~g} \mathrm{~K}_{2} \mathrm{HPO}$, $0 \cdot 1 \mathrm{~g} \mathrm{MgCl}_{2} \cdot 6 \mathrm{H}_{2} \mathrm{O}, 1 \cdot 0 \mathrm{~g} \mathrm{NH}_{4} \mathrm{Cl}, 0 \cdot 4 \mathrm{~g} \mathrm{Na}_{2} \mathrm{~S} .9 \mathrm{H}_{2} \mathrm{O}, 0.001 \mathrm{~g}$ resazurin, $0 \cdot 1 \mathrm{~g}$ yeast extract, $2 \mathrm{ml}$ vitamin solution (Wolin et al., 1963) and $1 \mathrm{ml}$ trace mineral solution (Whitman et al., 1982); the final $\mathrm{pH}$ was adjusted to $9 \cdot 5$. Filter paper or microcrystalline cellulose $\left(5 \mathrm{~g} \mathrm{l}^{-1}\right.$; Sigma $)$ was used as the substrate. The gas phase was composed of high-purity nitrogen gas. Serial dilutions were performed in Hungate tubes with a filter paper substrate. Cultures on the $10^{-9}$ dilution with one morphotype observed microscopically were chosen for subsequent 'roll-tube' serial dilution purification. Upon inoculation of 'roll-tubes' containing a medium with $3 \%(\mathrm{w} / \mathrm{v})$ agar and D-glucose, colonies appeared after $3-4$ days incubation at $35^{\circ} \mathrm{C}$. These colonies were white to yellowish-cream in colour and were round to convex lens shaped (in deep agar) with a diameter of $0 \cdot 5-1 \cdot 3 \mathrm{~mm}$. The colonies were also circular with smooth, thin edges and a darker coloured centre that had a denser consistency. One of the colonies from the $10^{-9}$ dilution was chosen as the type strain and was designated $\mathrm{SCA}^{\mathrm{T}}$. Unless specified otherwise, all subsequent incubations were performed at $35-37^{\circ} \mathrm{C}$. During the substrate utilization tests, the purity of the culture was checked by reverse inoculation to the first substrate. The culture purity was also routinely monitored microscopically.

Cell morphology of the novel isolate was examined under a Fisher Micromaster phase-contrast microscope. Cells of strain $\mathrm{SCA}^{\mathrm{T}}$ were long, straight rods with rounded ends and ranged from 0.4 to $0.5 \mu \mathrm{m}$ in width and from 2.5 to $5.0 \mu \mathrm{m}$ in length. Cells were motile and Gram-positive. Spores were round and located terminally without swelling sporangium. Cells occurred singly, in pairs or in short slightly curved chains. Images of cells of strain $\mathrm{SCA}^{\mathrm{T}}$ viewed with an Olympus BX41 light microscope equipped with a CytoViva 150 Illumination System (Vodyanoy, 2005) are available as Supplementary Fig. S1 in IJSEM Online.

Growth of the culture was determined by direct cell counting under a microscope or by measuring the optical density at $595 \mathrm{~nm}$ (Genesis 5; Spectronic Instruments). Catalase activity was determined based on the reaction with hydrogen peroxide (Gerhardt et al., 1994). Substrates were added to the medium at concentrations of $3 \mathrm{~g} \mathrm{l}^{-1}$. The medium also contained $0 \cdot 1 \mathrm{~g}$ yeast extract $\mathrm{l}^{-1}$. Gases were measured using a Varian 3700 gas chromatograph equipped with a Porapak Q column and thermal conductivity/flame ionization detector. Nitrogen was used as the gas carrier.

The novel isolate was an obligate anaerobe and grew exclusively under anaerobic conditions. Strain $\mathrm{SCA}^{\mathrm{T}}$ was catalase-negative. It was obligately dependent upon $\mathrm{Na}^{+}$ ions and could not grow without $\mathrm{NaCl}$ (the experiment was performed on medium in which all sodium salts were substituted by potassium salts and all $\mathrm{Cl}^{-}$-containing salts were replaced by $\mathrm{SO}_{4}^{2-}$ salts). At a concentration of $0.5 \%$ $(\mathrm{w} / \mathrm{v}) \mathrm{NaCl}$, growth was observed after a significantly longer lag phase than at optimal growth conditions. Optimum growth was at $1 \% \mathrm{NaCl}$ on the medium for which the total salinity (with carbonate and bicarbonate salts) was $2 \%(\mathrm{w} /$ v). The $\mathrm{NaCl}$ range for growth was $0 \cdot 5-9 \cdot 0 \%(\mathrm{w} / \mathrm{v})$ (see Supplementary Fig. S2 in IJSEM Online). No growth was observed within 60 days at 0 or $10 \% \mathrm{NaCl}$. At $1 \% \mathrm{NaCl}$, strain $\mathrm{SCA}^{\mathrm{T}}$ grew in the $\mathrm{pH}$ range from $6 \cdot 7$ to $10 \cdot 0$, with optimum growth at $\mathrm{pH} 8 \cdot 5$ (see Supplementary Fig. S2). At a salt concentration of $3 \% \mathrm{NaCl}$ and $1 \%$ other salts in the test medium, strain $\mathrm{SCA}^{\mathrm{T}}$ grew at $\mathrm{pH} 7 \cdot 5$, but not at $\mathrm{pH} 7 \cdot 0$. In a medium without carbonate-containing salts at $\mathrm{pH} 7 \cdot 5$ (a medium used routinely for the growth of neutrophilic bacteria), growth was very poor; cell yield was low and extensive spore formation was observed, confirming that the novel isolate was truly alkaliphilic. Growth was not dependent on $\mathrm{CO}_{3}$ ions; good growth was observed on glycine-buffered medium at $\mathrm{pH} 9 \cdot 0$ without carbonatecontaining salts (three subsequent passages demonstrated good growth). Strain $\mathrm{SCA}^{\mathrm{T}}$ was mesophilic. Growth was observed at $10-45^{\circ} \mathrm{C}$, with optimal growth at $35^{\circ} \mathrm{C}$ (Supplementary Fig. S2 in IJSEM Online).

Strain $\mathrm{SCA}^{\mathrm{T}}$ had a chemo-organoheterotrophic metabolism and was capable of growth on a range of substrates (see Table 1 and the species description below). Growth on cellulose and filter paper was slow and weak and required $0 \cdot 1 \mathrm{~g}$ yeast extract $1^{-1}$; filter paper was never completely hydrolysed. Hence strain $\mathrm{SCA}^{\mathrm{T}}$ could be considered as a facultatively cellulolytic bacterium.

Strain $\mathrm{SCA}^{\mathrm{T}}$ was capable of respiration by the Stickland reaction on the amino acid pairs listed in the species description. The only gaseous metabolic product of the culture grown on D-glucose was $\mathrm{CO}_{2}$; no hydrogen was detected. In the liquid phase, only acetate was detected. The same metabolic products were detected during growth with cellulose, glycerol and pyruvate. Therefore, the novel isolate is an acetogen. Vitamins and yeast extract $\left(0 \cdot 1-0 \cdot 5 \mathrm{~g}^{-1}\right)$ stimulated growth.

Antibiotic inhibition was tested at a concentration of $250 \mu \mathrm{g} \mathrm{ml}^{-1}$ (except for chloramphenicol, which was tested at $125 \mu \mathrm{g} \mathrm{ml}^{-1}$ ) and the results are given in the species description. Growth with ampicillin exhibited a prolonged lag phase (3-4 days).

For extraction of fatty acid methyl esters, strain $\mathrm{SCA}^{\mathrm{T}}$ was incubated for 4 days at $22{ }^{\circ} \mathrm{C}$ on the medium described above (with D-fructose as a substrate). Other reference strains (Clostridium formicaceticum ATCC $27076^{\mathrm{T}}$ and Clostridium aceticum ATCC $35044^{\mathrm{T}}$ ) received from the ATCC for comparative study were incubated at the same conditions on ATCC 1612 medium, which is very close in 
Table 1. Characteristics of strain $\mathrm{SCA}^{\top}$ and its phylogenetically closest related taxa

Taxa: 1, strain $\mathrm{SCA}^{\mathrm{T}}$; 2, Clostridium formicaceticum ATCC $27076^{\mathrm{T}}$ (data from Andreesen et al., 1970); 3, Clostridium aceticum ATCC $35044^{\mathrm{T}}$ (Wieringa, 1940; Braun et al., 1981). +, Positive; -, negative; ND, no data. All three taxa are able to grow on D-fructose, D-ribose and pyruvate; none is able to use glycine, lactose or D-mannose. None of the taxa produces hydrogen.

\begin{tabular}{|c|c|c|c|}
\hline Characteristic & 1 & 2 & 3 \\
\hline Cell size $(\mu \mathrm{m})$ & $0 \cdot 4-0 \cdot 5 \times 2 \cdot 5-5 \cdot 0$ & $1 \cdot 2-2 \times 5-12$ & $0 \cdot 8-1 \cdot 0 \times 5 \cdot 0$ \\
\hline $\mathrm{NaCl}$ optimum (range) (\%) & $2(0 \cdot 5-9 \cdot 0)$ & ND & ND \\
\hline Temperature optimum (range) $\left({ }^{\circ} \mathrm{C}\right)$ & $35(10-45)$ & $37(28-44)$ & $30(22-45)$ \\
\hline D-Maltose & + & ND & - \\
\hline Sucrose & + & - & - \\
\hline D-Mannitol & + & + & - \\
\hline Starch & + & - & - \\
\hline Pectin & + & + & ND \\
\hline Glycerol & + & + & - \\
\hline Lactate & + & + & - \\
\hline Formate & - & - & + \\
\hline L-Serine & + & ND & + \\
\hline L-Threonine & - & ND & - \\
\hline \multicolumn{4}{|l|}{ Products of glucose fermentation: } \\
\hline Formate & - & + & ND \\
\hline Acetate & + & + & $+^{*}$ \\
\hline Lactate & - & ND & $\mathrm{ND}$ \\
\hline DNA G $+\mathrm{C}$ content $(\mathrm{mol} \%)$ & $34 \cdot 2$ & 34 & 33 \\
\hline DNA-DNA hybridization value with strain $\mathrm{SCA}^{\mathrm{T}}(\%)$ & 100 & 13 & 11 \\
\hline
\end{tabular}

${ }^{\star}$ Forms acetate from $\mathrm{H}_{2}+\mathrm{CO}_{2}$ (classical acetogen).

composition to that used for the novel isolate. The extraction and analysis procedures were as described previously (Pikuta et al., 2003b). The major fatty acids of strain $\mathrm{SCA}^{\mathrm{T}}$ were $\mathrm{C}_{14: 0}$, iso- $\mathrm{C}_{15: 0}, \mathrm{C}_{16: 1} \omega 9 c$ and $\mathrm{C}_{16: 0}$, whereas those of the two reference strains were $C_{14: 0}$, $\mathrm{C}_{16: 1} \omega 9 c$ and $\mathrm{C}_{16: 0}$ (no iso- $\mathrm{C}_{15: 0}$; Table 2).

The $\mathrm{G}+\mathrm{C}$ content of the genomic DNA of strain $\mathrm{SCA}^{\mathrm{T}}$ was determined as described in Mesbah et al. (1989), except that 2 units of S1 nuclease were used instead of P1 nuclease and the nuclease degradation was performed in a $20 \mathrm{mM}$ sodium acetate buffer, $\mathrm{pH} 5 \cdot 0$. The total $\mathrm{G}+\mathrm{C}$ content of the purified genomic DNA for strain $\mathrm{SCA}^{\mathrm{T}}$ was $34 \cdot 2 \pm 0 \cdot 2 \mathrm{~mol} \%($ mean $\pm \mathrm{SD}, n=12)$.

For $16 \mathrm{~S}$ rRNA gene sequence analysis, cells were lysed by sonication and the genomic DNA was isolated following phenol/chloroform extraction and ethanol precipitation (Sambrook et al., 1989). The 16S rRNA genes were PCR amplified with primers EB-10F (5'AGTTTGATCCTGGCTC, positions $10-25$ according to the Escherichia coli numbering system) and EB-1530R (5' AAGGAGGTGATCCAGCC, positions 1541-1525).

The amplified 16S rRNA genes were sequenced directly in an ABI PRISM 310 Genetic Analyser (Applied Biosystems) with the 16S rRNA internal primers (Namwong et al., 2005). In addition, to confirm the sequence of both end regions, the product purified by recovery from agarose gels using a GenElute Minus EtBr spin column (Sigma) was cloned into pT7 Blue vectors (Novagene), transformed in competent cells (E. coli JCM 109) and the plasmid DNAs were sequenced with the vector primers. Multiple alignments of the sequence were performed with CLUSTAL $\mathrm{X}$ (Thompson et al., 1997). The alignment was manually verified and edited. After gaps and ambiguous bases were eliminated, evolutionary distances were calculated (see below) and a phylogenetic tree (Fig. 1) was constructed by using the neighbour-joining method (Saitou \& Nei, 1987). Confidence values of branches of the phylogenetic tree were determined using bootstrap analyses (Felsenstein, 1985) based on 1000 resamplings. 
Table 2. Cellular fatty acid content of strain $\mathrm{SCA}^{\top}$ and related taxa

Taxa: 1, strain SCA ${ }^{\mathrm{T}}$; 2, Clostridium aceticum ATCC $35044^{\mathrm{T}}$; 3, Clostridium formicaceticum ATCC $27076^{\mathrm{T}}$. Values are percentages $(\mathrm{w} / \mathrm{w})$ of total fatty acids. DMA, dimethyl acetate; FAME, fatty acid methyl ester.

\begin{tabular}{|c|c|c|c|}
\hline Fatty acid & 1 & 2 & 3 \\
\hline iso- $\mathrm{C}_{14: 0}$ FAME & $2 \cdot 32$ & $0 \cdot 00$ & $0 \cdot 00$ \\
\hline $\mathrm{C}_{14: 0}$ FAME & $12 \cdot 67$ & $23 \cdot 99$ & $28 \cdot 68$ \\
\hline iso- $\mathrm{C}_{15: 0}$ FAME & $16 \cdot 99$ & $0 \cdot 00$ & $0 \cdot 00$ \\
\hline anteiso- $\mathrm{C}_{15: 0}$ FAME & $2 \cdot 29$ & $8 \cdot 13$ & $4 \cdot 19$ \\
\hline Summed feature $4^{\star}$ & $3 \cdot 22$ & $12 \cdot 12$ & $5 \cdot 09$ \\
\hline $\mathrm{C}_{16: 0} \mathrm{ALDE}$ & $3 \cdot 07$ & $9 \cdot 02$ & $11 \cdot 03$ \\
\hline $\mathrm{C}_{15: 0}$ FAME & $1 \cdot 04$ & $0 \cdot 00$ & $0 \cdot 00$ \\
\hline iso- $\mathrm{C}_{15: 0}$ DMA & $0 \cdot 61$ & $0 \cdot 00$ & $0 \cdot 00$ \\
\hline iso- $\mathrm{C}_{16: 0}$ FAME & $1 \cdot 05$ & $0 \cdot 00$ & $0 \cdot 00$ \\
\hline $\mathrm{C}_{16: 1} \omega 7 c$ FAME & $3 \cdot 24$ & $0 \cdot 00$ & $0 \cdot 00$ \\
\hline $\mathrm{C}_{16: 1} \omega 9 c$ FAME & $21 \cdot 12$ & $30 \cdot 02$ & $22 \cdot 49$ \\
\hline $\mathrm{C}_{16: 1} \omega 11 c$ FAME & $1 \cdot 1$ & $0 \cdot 00$ & $0 \cdot 00$ \\
\hline $\mathrm{C}_{16: 0} \mathrm{FAME}$ & $20 \cdot 93$ & $8 \cdot 32$ & $18 \cdot 99$ \\
\hline $\mathrm{C}_{16: 1} \omega 9 c$ FAME & $2 \cdot 82$ & $3 \cdot 62$ & $1 \cdot 95$ \\
\hline $\mathrm{C}_{16: 0} \mathrm{DMA}$ & $3 \cdot 78$ & $4 \cdot 77$ & $5 \cdot 7$ \\
\hline iso- $\mathrm{C}_{17: 0}$ FAME & $2 \cdot 02$ & $0 \cdot 00$ & $0 \cdot 00$ \\
\hline $\mathrm{UN} 17 \cdot 103$ iso- $\mathrm{C}_{17: 0} \mathrm{DMA}$ & $1 \cdot 01$ & $0 \cdot 00$ & $0 \cdot 00$ \\
\hline $\mathrm{C}_{18: 0}$ FAME & $0 \cdot 72$ & $0 \cdot 00$ & $0 \cdot 00$ \\
\hline
\end{tabular}

${ }^{*}$ Summed feature 4 represents unresolved $\mathrm{C}_{15: 2}$ FAME and/or $\mathrm{C}_{15: 1} \omega 7 c$.

The sequence determined (1495 nt) was compared with all sequences currently available in the GenBank database and appeared to be highly similar to those from species of clostridial cluster XI (Collins et al., 1994). The phylogenetic tree was constructed with representative strains of clostridial cluster XI by comparing 1202 nucleotide positions as shown in Fig. 1. Strain $\mathrm{SCA}^{\mathrm{T}}$ formed a cluster with the type strains of $C$. aceticum and C. formicaceticum, with sequence similarity values, based on pairwise comparison, of $97 \cdot 0 \%$ (1479 positions) and $96.6 \%$ (1366 positions), respectively. Strain $\mathrm{SCA}^{\mathrm{T}}$ was distantly related to other members of clostridial cluster XI $(<94 \cdot 2 \% 16 \mathrm{~S}$ rRNA gene sequence similarity).

DNA-DNA hybridization studies, performed according to the method of Ezaki et al. (1989), revealed that strain SCA ${ }^{\mathrm{T}}$ was not a member of either of these two species, showing low hybridization values to C. formicaceticum ATCC $27076^{\mathrm{T}}$ and C. aceticum ATCC $35044^{\mathrm{T}}$ (13 and $11 \%$, respectively).

Strain $\mathrm{SCA}^{\mathrm{T}}$ was isolated from a sample of anaerobic sediments of soda Owens Lake, which is a highly alkaline, evaporitic, carbonate-saturated lake remnant that has undergone the complete cycle of synthesis and degradation of organic matter. Photosynthetic prokaryotes (cyanobacteria and purple bacteria linked to the sulfur cycle) represent the primary producers of organic matter in the lake; the decomposers are represented by cellulolytic, sugarlytic, proteolytic, bacteriolytic, sulfate-reducers, together with other secondary anaerobes (Pikuta et al., 2005).

The novel isolate occurs within a group of obligately anaerobic, alkalitolerant and alkaliphilic species of clostridial cluster XI. The role of this novel bacterium within the community studied is polyfunctional. The organism participates in cellulose decomposition as a primary anaerobe, it also performs hydrolysis of bimeric and monomeric sugars and products of proteolysis as a dissipotroph and finally it performs the role of a secondary anaerobe by using low-energy molecules of organic acids such as lactic, pyruvic and citric acid.

While this paper was in preparation, the anaerobic, alkaliphilic bacterium Clostridium alkalicellulosi Z $-7026^{\mathrm{T}}$ (capable of growing exclusively on cellulose, xylan and

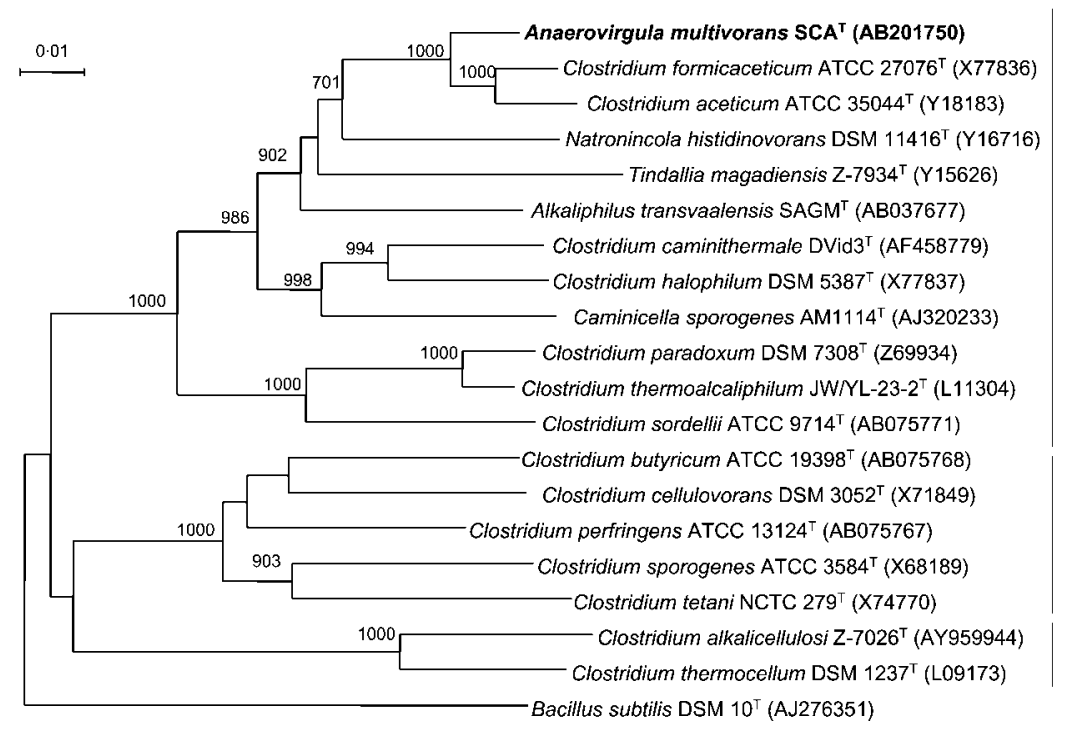

Fig. 1. Unrooted phylogenetic tree derived from 16S rRNA gene sequences showing the relationship of strain $\mathrm{SCA}^{\top}$ to other taxa of clostridial cluster XI (Collins et al., 1994). The tree was constructed by the neighbourjoining method. Numbers indicate bootstrap values based on 1000 resamplings. Roman numerals to the right designate clostridial clusters as defined by Collins et al. (1994). Bar, $1 \%$ sequence divergence. 
Table 3. Differential characteristics of the genus Anaerovirgula gen. nov. and other alkaliphilic, acetogenic, anaerobic, mesophilic genera

Genera: 1, Anaerovirgula; 2, Tindallia (data from Kevbrin et al., 1998); 3, Clostridium (Hippe et al., 1992); 4, Natronincola (Zhilina et al., 1998); 5, Alkaliphilus (Takai et al., 2001); 6, Anoxynatronum (Garnova et al., 2003); 7, Natroniella (Zhilina et al., 1996). +, Positive; -, negative; +/-, variable; ND, no data. An (atl), aerotolerant anaerobe; Oblig an, obligate anaerobe.

\begin{tabular}{|c|c|c|c|c|c|c|c|}
\hline Characteristic & 1 & 2 & 3 & 4 & 5 & 6 & 7 \\
\hline Gram reaction & + & + & $+1-$ & + & + & + & - \\
\hline Metabolism & Oblig an & Oblig an & An (atl) & Oblig an & Oblig an & An (atl) & Oblig an \\
\hline \multicolumn{8}{|l|}{ Reduction of: } \\
\hline $\mathrm{SO}_{4}^{2-}$ to $\mathrm{H}_{2} \mathrm{~S}$ & - & - & - & - & $-\dagger$ & - & - \\
\hline \multicolumn{8}{|l|}{ Activity of: } \\
\hline Catalase & - & - & - & $\mathrm{ND}$ & $\mathrm{ND}$ & + & $\mathrm{ND}$ \\
\hline Oxidase & - & - & - & $\mathrm{ND}$ & $\mathrm{ND}$ & $\mathrm{ND}$ & $\mathrm{ND}$ \\
\hline $\mathrm{NaCl}(3-12 \%)$ requirement & - & + & $+1-$ & + & - & + & + \\
\hline $\mathrm{CO}_{3}^{2-}$ requirement & - & - & - & + & - & + & + \\
\hline
\end{tabular}

${ }^{\star}$ Oligospore-forming.

$\dagger$ Reduction of sulfur, thiosulfate and fumarate.

‡Using only glutamate.

§omoacetogen.

cellobiose) was described by Zhilina et al. (2005). This bacterium belongs to clostridial cluster III. This highly specialized cellulose- and xylan-decomposer is incapable of fermenting monosaccharides, disaccharides other than cellobiose, other polymeric sugars or proteins. These properties are quite different from those of strain $\mathrm{SCA}^{\mathrm{T}}$.

It is interesting that strain $\mathrm{SCA}^{\mathrm{T}}$ is capable of growth on Lisomers of sugars, which suggests the possible presence of alkaliphilic isomerases in its metabolism. The distinguishing features of the novel isolate and closely related species $C$. formicaceticum and C. aceticum are shown in Table 1. Phenotypic differences between the novel isolate and $C$. formicaceticum ATCC $27076^{\mathrm{T}}$ are as follows: cell size (diameter of cells of strain $\mathrm{SCA}^{\mathrm{T}}$ is three times smaller), ability to ferment D-glucose, sucrose, D-mannitol, methanol and lactate. Furthermore, C. aceticum ATCC $35044^{\mathrm{T}}$ is a classical homoacetogen that is capable of growth on $\mathrm{H}_{2}+\mathrm{CO}_{2}$, but strain $\mathrm{SCA}^{\mathrm{T}}$ cannot grow on hydrogen or $\mathrm{H}_{2}+\mathrm{CO}_{2}$ and the $\mathrm{G}+\mathrm{C}$ content of the genomic DNA is different by $1 \mathrm{~mol} \%$.

The fatty acid content of strain SCA ${ }^{\mathrm{T}}$ is also very different from that of the two phylogenetically closest related species. The $\mathrm{C}_{14: 0}$ fatty acid content of strain $\mathrm{SCA}^{\mathrm{T}}$ is less than half that of C. formicaceticum ATCC $27076^{\mathrm{T}}$ and C. aceticum ATCC $35044^{\mathrm{T}}$, and strain $\mathrm{SCA}^{\mathrm{T}}$ contains only one-third the content of $\mathrm{C}_{16: 0}$ aldehydes present in the latter two strains. Finally, iso-branched fatty acids are abundant in strain $\mathrm{SCA}^{\mathrm{T}}$ $(24.0 \%$ in total), but completely absent in the other two organisms (Table 2).

Strain $\mathrm{SCA}^{\mathrm{T}}$ can also be differentiated from recognized genera in clostridial cluster XI, such as Natroninocola, Tindallia, Alkaliphilus and Caminicella, with less than $94 \cdot 2 \% 16 \mathrm{~S}$ rRNA sequence similarity to the type species of these genera. In addition to its phylogenetic distinctiveness, strain $\mathrm{SCA}^{\mathrm{T}}$ can be differentiated from these nonClostridium genera based on its phenotypic properties (Table 3). Members of the genus Natronincola are halophilic ( $>4 \%$ ) and do not ferment sugars; representatives of the genus Tindallia have higher genomic DNA G $+\mathrm{C}$ contents and no iso- $\mathrm{C}_{15}$ fatty acids and species of the genus Alkaliphilus have less $\mathrm{C}_{16: 1}$ fatty acid methyl esters. On the basis of these data, strain $\mathrm{SCA}^{\mathrm{T}}$ should be classified in a new genus in clostridial cluster XI.

Our 16S rRNA gene sequence analysis reveals that strain $\mathrm{SCA}^{\mathrm{T}}$ represents a member of clostridial cluster XI and is closely related to $C$. formicaceticum and C. aceticum. However, the type species of the genus Clostridium (Clostridium butyricum) is located in clostridial cluster I, a completely separate phylogenetic cluster (as shown in Fig. 1). Thus, strain $\mathrm{SCA}^{\mathrm{T}}$ (as well as C. formicaceticum 
and $C$. aceticum) should in principle be accommodated within a separate new genus. However, given the differences in metabolism, low DNA-DNA relatedness value and the significantly different fatty acid profiles, we do not consider it appropriate at this time to move the latter two species to a new genus. Further comparative studies will need to be carried out to clarify the taxonomic status of C. formicaceticum and $C$. aceticum, which may subsequently be reclassified and included in the new genus Anaerovirgula.

On the basis of phenotypic and genotypic characteristics, including Gram-positive cell walls, spore formation, obligately anaerobic and fermentative metabolism, mesophilic and alkaliphilic physiology, dependence on $\mathrm{NaCl}$ for growth, fatty acid content, $16 \mathrm{~S}$ rRNA gene sequence divergence and levels of DNA-DNA relatedness, strain $\mathrm{SCA}^{\mathrm{T}}$ is proposed as the type strain of a novel species in a new genus, Anaerovirgula multivorans gen. nov., sp. nov.

\section{Description of Anaerovirgula gen. nov.}

Anaerovirgula (An.aer.o.vir'gu.la. Gr. pref. an not; Gr. n. aer aeros, air; L. fem. n. virgula a small rod; N.L. fem. n. Anaerovirgula an anaerobic small rod).

Gram-positive, spore-forming, small $(2 \cdot 5-5 \cdot 0 \mu \mathrm{m})$ rodshaped cells that occur alone, in pairs or in short chains. Obligately anaerobic, and catalase-negative. Alkaliphilic and mesophilic. Chemo-organotrophic, with a fermentative metabolism (sugars and proteolysis products) and capable of respiration by the Stickland reaction. The fatty acid profile differs from that of members of the same clostridial cluster in the following respects: presence of iso- $\mathrm{C}_{15: 0}$ fatty acid methyl esters, reduced quantity of $\mathrm{C}_{14: 0}$ fatty acid methyl esters and significantly reduced quantity of $\mathrm{C}_{16: 0}$ aldehydes. The $\mathrm{G}+\mathrm{C}$ content of the genomic DNA is around $34 \mathrm{~mol} \%$. Belongs to clostridial cluster XI as defined by Collins et al. (1994).

The type and only species is Anaerovirgula multivorans.

\section{Description of Anaerovirgula multivorans sp. nov.}

Anaerovirgula multivorans (mul.ti.vo'rans. L. adj. multus many; L. part. adj. vorans devouring; N.L. part. adj. multivorans devouring numerous kinds of substrates).

Cells are motile, straight rods with rounded ends, $0 \cdot 4-0 \cdot 5 \times 2 \cdot 5-5 \cdot 0 \mu \mathrm{m}$ in size. Spores are terminally located. Growth occurs between 10 and $45^{\circ} \mathrm{C}$ (optimum $35^{\circ} \mathrm{C}$ ), and at $\mathrm{pH}^{22{ }^{\circ} \mathrm{C}} 6 \cdot 7-10 \cdot 0$ (optimum $\mathrm{pH} 8 \cdot 5$ ). Range of $\mathrm{NaCl}$ for growth is $0.5-9 \%(\mathrm{w} / \mathrm{v})$, with optimum growth at $1-2 \%$ $(\mathrm{w} / \mathrm{v}) \mathrm{NaCl}$. Heterotrophic growth occurs with lactate, pyruvate, citrate, glycerol, D-mannitol, D-glucose, D-fructose, D-maltose, D-trehalose, D-ribose, L-ribose, L-arabinose, sucrose, pectin, starch, D-cellobiose, cellulose, filter paper, triethylamine, peptone, yeast extract, Casamino acids, chitin, L-cysteine, L-aspartic acid, L-arginine, L-histidine, trans-4-hydroxy-L-proline, L-serine, L-alanine, L-lysine and
L-glutamine. No growth on $\mathrm{H}_{2}+\mathrm{CO}_{2}, \mathrm{H}_{2}$ alone, formate, acetate, propionate, butyrate, acetone, ethanol, methanol, lactose, D-arabinose, L-mannose, L-glucose, D-fucose, L-fucose, betaine, trimethylamine, D-arginine, L-proline, D-proline, D-lysine, D-serine, glycine, L-tyrosine, L-threonine, D-threonine, L-cystine or L-valine. Produces $\mathrm{CO}_{2}$ but not $\mathrm{H}_{2}$ during fermentation. Capable of respiration by the Stickland reaction on the following amino acid pairs: L-proline $+\mathrm{L}$-isoleucine and L-proline $+\mathrm{L}$-leucine. No growth on L-proline $+\mathrm{L}$-valine, glycine $+\mathrm{L}$-leucine, glycine $+\mathrm{L}$-isoleucine, glycine $+\mathrm{L}$-valine or L-tryptophan $+\mathrm{L}$ valine. Resistant to ampicillin and kanamycin, but sensitive to gentamicin, tetracycline, rifampicin and chloramphenicol. The $\mathrm{G}+\mathrm{C}$ content of the genomic DNA is $34 \cdot 2 \mathrm{~mol} \%$.

The type strain, $\mathrm{SCA}^{\mathrm{T}} \quad\left(=\mathrm{ATCC} \quad \mathrm{BAA}-1084^{\mathrm{T}}=\mathrm{JCM}\right.$ $12857^{\mathrm{T}}=$ DSM $17722^{\mathrm{T}}=$ CIP $\left.107910^{\mathrm{T}}\right)$, was isolated from anaerobic, alkaline mud sediments of Owens Lake, California, USA.

\section{Acknowledgements}

We thank the NASA/MSFC CDDF Program for funding and Aetos Technologies, Inc. for providing the CytoViva equipment for photomicroscopy. We also thank Professor J. P. Euzéby for help with the Latin.

\section{References}

Andreesen, J. R., Gottschalk, G. \& Schlegel, H. G. (1970). Clostridium formicoaceticum nov. spec. Isolation, description and distinction from C. aceticum and C. thermoaceticum. Arch Microbiol 72, 154-174.

Braun, M., Mayer, F. \& Gottschalk, G. (1981). Clostridium aceticum (Wieringa), a microorganism producing acetic acid from molecular hydrogen and carbon dioxide. Arch Microbiol 128, 288-293.

Collins, M. D., Lawson, P. A., Willems, A., Cordoba, J. J., FernandezGarayzabal, J., Garcia, P., Cai, J., Hippe, H. \& Farrow, J. A. (1994). The phylogeny of the genus Clostridium: proposal of five new genera and eleven new species combinations. Int J Syst Bacteriol 44, 812-826.

Ezaki, T., Hashimoto, Y. \& Yabuuchi, E. (1989). Fluorometric deoxyribonucleic acid-deoxyribonucleic acid hybridization in microdilution wells as an alternative to membrane filter hybridization in which radioisotopes are used to determine genetic relatedness among bacterial strains. Int J Syst Bacteriol 39, 224-229.

Felsenstein, J. (1985). Confidence limits on phylogenies: an approach using the bootstrap. Evolution 39, 783-791.

Garnova, E. S., Zhilina, T. N., Tourova, T. P. \& Lysenko, A. M. (2003). Anoxynatronum sibiricum gen. nov., sp. nov. alkaliphilic saccharolytic anaerobe from cellulolytic community of Nizhnee Beloe (Transbaikal region). Extremophiles 7, 213-220.

Gerhardt, P., Murray, R. G. E., Wood, W. A. \& Krieg, N. R. (1994). Methods for General and Molecular Bacteriology. Washington, DC: American Society for Microbiology.

Hippe, H., Andreesen, J. R. \& Gottschalk, G. (1992). The genus Clostridium-Nonmedical. In The Prokaryotes, 2nd edn, vol. 2, pp. 1800-1866. Edited by A. Balows, H. G. Trüper, M. Dworkin, W. Harder \& K.-H. Schleifer. New York: Springer. 
Hoover, R. B., Pikuta, E. V., Bej, A. K., Marsic, D., Whitman, W. B., Tang, J. \& Krader, P. (2003). Spirochaeta americana sp. nov., a new haloalkaliphilic, obligately anaerobic spirochete isolated from soda Mono Lake in California. Int J Syst Evol Microbiol 53, 815-821.

Kevbrin, V. V., Zhilina, T. N., Rainey, F. A. \& Zavarzin, G. A. (1998). Tindallia magadii gen. nov., sp. nov. an alkaliphilic anaerobic ammonifier from soda lake deposits. Curr Microbiol 37, 94-100.

Lynd, L. R., Weimer, P. J., van Zyl, W. H. \& Pretorius, I. S. (2002). Microbial cellulose utilization: fundamentals and biotechnology. Microbiol Mol Biol Rev 66, 506-577.

Mesbah, M., Premachandran, U. \& Whitman, W. (1989). Precise measurement of the $\mathrm{G}+\mathrm{C}$ content of deoxyribonucleic acid by highperformance liquid chromatography. Int J Syst Bacteriol 39, 159-167.

Namwong, S., Tanasupawat, S., Smitinont, T., Visessanguan, W., Kudo, T. \& Itoh, T. (2005). Isolation of Lentibacillus salicampi strains and Lentibacillus juripiscarius sp. nov. from fish sauce in Thailand. Int J Syst Evol Microbiol 55, 315-320.

Pikuta, E. V., Hoover, R. B., Bej, A. K., Marsic, D., Whitman, W. B., Cleland, D. \& Krader, P. (2003a). Desulfonatronum thiodismutans sp. nov., a novel alkaliphilic, sulfate-reducing bacterium capable of lithoautotrophic growth. Int J Syst Evol Microbiol 53, 1327-1332.

Pikuta, E. V., Hoover, R. B., Bej, A. K., Marsic, D., Detkova, E. N., Whitman, W. B. \& Krader, P. (2003b). Tindallia californiensis sp. nov., a new anaerobic, haloalkaliphilic, spore-forming acetogen isolated from soda Mono Lake in California. Extremophiles 7, 327-334.

Pikuta, E. V., Itoh, T. \& Hoover, R. B. (2005). Anaerobic decomposition of cellulose by alkaliphilic microbial community of Owens Lake, California. In Astrobiology and Planetary Missions, Proceedings of the SPIE Conference 2005, vol. 5906, pp. 29-40. Edited by R. B. Hoover, G. V. Levin, A. Y. Rozanov \& G. R. Gladstone. Bellingham, WA; SPIE.

Saitou, N. \& Nei, M. (1987). The neighbor-joining method: a new method for reconstructing phylogenetic trees. Mol Biol Evol 4, 406-425.
Sambrook, J., Fritch, E. F. \& Maniatis, T. (1989). Molecular Cloning: A Laboratory Manual, 2nd edn. Cold Spring Harbor, NY: Cold Spring Harbor Laboratory Press.

Takai, K., Moser, D. P., Onstott, T. C., Spoelstra, N., Pfiffner, S. M., Dohnalkova, A. \& Fredrickson, J. K. (2001). Alkaliphilus transvaalensis gen. nov., sp. nov., an extremely alkaliphilic bacterium isolated from a deep South African gold mine. Int J Syst Evol Microbiol 51, $1245-1256$.

Thompson, J. D., Gibson, T. J., Plewniak, F., Jeanmougin, F. \& Higgins, J. D. (1997). The CLUSTAL_X windows interface: flexible strategies for multiple sequence alignment aided by quality analysis tools. Nucleic Acids Res 25, 4876-4882.

Vodyanoy, V. (2005). High resolution light microscopy of living cells. Microsc Today 13, 26-28.

Whitman, W. B., Ankwanda, E. \& Wolfe, R. S. (1982). Nutrition and carbon metabolism of Methanococcus voltae. J Bacteriol 149, 852-863.

Wieringa, K. T. (1940). The formation of acetic acid from carbon dioxide and hydrogen by anaerobic spore-forming bacteria. Antonie van Leeuwenhoek 6, 251-262.

Wolin, E. A., Wolin, M. J. \& Wolf, R. S. (1963). Formation of methane by bacterial extracts. J Biol Chem 238, 2882-2886.

Zhilina, T. N., Zavarzin, G. A., Detkova, E. N. \& Rainey, F. A. (1996). Natroniella acetigena gen. nov., sp. nov., an extremely haloalkaliphilic, homoacetic bacterium: a new member of Haloanaerobiales. Curr Microbiol 32, 320-326.

Zhilina, T. N., Detkova, E. N., Rainey, F. A., Osipov, G. A., Lysenko, A. M., Kostrikina, N. A. \& Zavarzin, G. A. (1998). Natronoincola histidinovorans gen. nov., sp. nov., a new alkaliphilic acetogenic anaerobe. Curr Microbiol 37, 177-185.

Zhilina, T. N., Kevbrin, V. V., Tourova, T. P., Lysenko, A. M., Kostrikina, N. A. \& Zavarzin, G. A. (2005). Clostridium alkalicellum sp. nov., an obligately alkaliphilic cellulolytic bacterium from a soda lake in the Baikal region. Microbiology (English translation of Mikrobiologiia) 74, 557-566. 